\title{
News discourses on distant suffering: a Critical Discourse Analysis of the 2003 SARS outbreak
}

\section{Stijn Joye}

Discourse \& Society, 21(5): 586-601.

\section{Abstract and keywords}

News carries a unique signifying power, a power to represent events in particular ways (Fairclough 1995). Applying Critical Discourse Analysis and Chouliaraki's theory on the mediation of suffering (2006), this article explores the news representation of the 2003 global SARS outbreak. Following a case-based methodology, we investigate how two Belgian television stations have covered the international outbreak of SARS. By looking into the mediation of four selected discursive moments, underlying discourses of power, hierarchy and compassion were unraveled. The analysis further identified the key role of proximity in international news reporting and supports the claim that Western news media mainly reproduce a Euro-American centered world order. This article argues that news coverage of international crises such as SARS constructs and maintains the socio-cultural difference between 'us' and 'them' as well as articulating global power hierarchies and a division of the world in zones of poverty and prosperity, danger and safety.

Keywords: news discourses, SARS, Critical Discourse Analysis, television news, distant suffering, proximity, representation of 'Self' and 'Other', discourses of power and hierarchy, compassion 


\section{Short bionote}

Stijn Joye $(\mathrm{PhD})$ is researcher in the Department of Communication Studies at Ghent University (Belgium) where he is a member of the 'Centre for Cinema and Media Studies' (CIMS) and 'Center for Journalism Studies' (CJS). His areas of research and publication include international and foreign news, global news agencies, the representation of suffering, and the concept of artistic imitation in film. He has recently finalized a $\mathrm{PhD}$ on the news media coverage of international disasters. 


\section{News discourses on distant suffering: a Critical Discourse Analysis of the 2003 SARS outbreak}

\section{Introduction}

In November of 2002 China's Southern province of Guangdong was affected by a "strange contagious disease" (Associated Press, 2003) that infected and killed several people within the region. As the Chinese government initially treated the outbreak with extreme secrecy, the disease did not reach the public spotlight until mid-February 2003. At that point, the mysterious epidemic could no longer be ignored as the 'severe acute respiratory syndrome' (SARS) has already spread to Hong Kong, Taiwan, Singapore, Vietnam and Canada. Responding to the global spread of SARS, the World Health Organization (WHO) declared the disease a "worldwide health threat" (Associated Press, 2003) on 15 March 2003 and commenced to issue travel advisories. In these first weeks of SARS's transnational outbreak, global news media generally conceived the disease as a local Asian issue and chose not to pay much attention to such distant suffering. Following the first (alleged) cases of SARS in Western European countries such as Germany, France and Belgium, Western media attention for SARS eventually peaked. Although most Western cases proved to be false, these events underscore the importance of proximity in steering a news media cycle and in articulating discourses of compassion and involvement.

Applying Critical Discourse Analysis (Fairclough, 1992, 1995) and Lilie Chouliaraki’s theory on the mediation of suffering $(2006,2008)$, this article explores the news discourses on SARS as articulated by two Flemish ${ }^{1}$ broadcasters, the public funded VRT and the commercial television channel VTM. Following a case-based methodology, we investigate how these two broadcasters have covered the international outbreak of SARS and attempt to 
unravel the underlying discourses of power, hierarchy and compassion by looking into the mediation of selected discursive moments and by analyzing the construction of 'Self' and 'Other' in news discourses on distant suffering. In the literature overview, we will first discuss the representation of the distant 'Other' in Western press. Related to this is the concept of proximity in international news reporting on crises. After this, we will briefly go into the literature on SARS, the model of Chouliaraki $(2006,2008)$ and the field of Critical Discourse Analysis (CDA).

\section{The mediated representation of distant suffering}

For most people living in the so-called developed world, disasters are 'a priori' foreign news. When a foreign society undergoes severe damage and incurs such losses to its members, most Western spectators receive this information not first-handed or by personal experience, but through the media. As Gaunt (1990: 3) rightly states, insofar as the information received from media shapes our view of the world, it is crucial to understand these processes. The processes under investigation in this article deal with the mediated representation of distant suffering (see Boltanski, 1999). According to Nederveen Pieterse (1990: 234), one of the main characteristics of such representation is that it is part of the production and reproduction of global social inequality. Chouliaraki (2006) confirms this and argues that the mediated representation of distant suffering reflects and consolidates the unequal economic and political power relations. She refers to the power of media to classify the world into categories of 'us' and 'the Other' and orientate (or not) the Western spectator towards the 'Other' in need. The latter is mainly located in developing countries as Belloni et al. (2000) argue that more than $90 \%$ of all disasters occur in the Third World. In Western media imagery, Third World people are however generally portrayed as the exotic 'Other', most typically characterized in terms of helplessness, negativity and as inferior to 'us' (Benthall, 1993; 
Chiang and Duann, 2007). Western press has always been charged with constructing such a reductive ideological contrast between 'us' and 'them' (Lee et al., 2002). These representations are often rooted in colonial history or are ideologically driven which adds on to the already incomplete and stereotypical portrayal of the 'Other' (cf. theories on Orientalism; Saïd, 1987). This idea "that hierarchies of place and human life are reproduced in Western news is not new in social research" (Chouliaraki, 2006: 8) and has been the subject of research from different traditions, including studies on disaster coverage.

Overlooking the field of research on disaster news coverage, several subfields can be identified. Of interest to this article is a rich strand of research that explores the factors and values that dictate the coverage of global emergencies. Proximity of the foreign event to the home country appears to have a substantial impact on the amount of coverage (Adams, 1986; Van Belle, 2000). In this article we refer to proximity as a meta-concept to indicate a number of related factors such as cultural affinity, historical links, geographical distance as well as psychological or emotional distance. All these factors express a certain relationship of involvement between the (Western) spectator and the (distant) sufferer or region affected by the emergency. This involvement can take many forms, but scholars have identified the presence of Western victims and Western (economic) self-interests as the most important predictors for an international disaster's newsworthiness (Adams, 1986; CARMA International, 2006; Kim and Lee, 2008). Related to this are findings from previous research that have demonstrated the often nationalistic and ethnocentric nature of international and foreign news coverage (Kamalipour, 2002; Kim and Lee, 2008). A review of the literature further identified important factors such as the geopolitical, economic and military importance of the affected region (Benthall, 1993; Singer and Endreny, 1993) as well as the severity of a disaster (Gans, 1979). Focusing on print and television news coverage of earthquakes, Gaddy 
and Tanjong (1986) as well as Simon (1997) for instance observed a strong relationship between the amount of coverage and the number of people killed.

\section{Academic research on SARS and its media coverage}

Applying these news factors to the case of SARS, it is easy to understand how the epidemic evolved into a global news event. Although the most severe effects were inflicted on the Asia Pacific region, SARS posed a potential health threat to countries around the globe, including Western Europe. The magnitude of SARS created news value for the international press as nearly forty countries reported cases of SARS and worldwide 8,096 known infected persons and 774 deaths were listed by the WHO (2003). SARS also had a severe impact on global tourism and economy with for instance a projected cost of US \$28 billion to East Asian economies (Beaudoin, 2007: 509). A study by Berry et al. (2007) further revealed that SARS was mainly reported on in terms of risk, underwriting its symbolic connotation of "mysterious" and "deadly".

Media studies have investigated the SARS outbreak from a wide variety of perspectives and methodological approaches. For some scholars (see Luther and Zhou, 2004; Zhang and Fleming, 2005; Zhang, 2006) the outbreak of SARS actually proved to be a unique case study of China, its media culture and policies. Leung and Huang (2007) for instance found the news frames on SARS stressing China's institutional mismanagement of the outbreak, bureaucratic obstacles, poor health system and primitive living conditions, thus resulting in an unfavorable representation of China as a negative 'Other'. Regarding the applied methodologies, it is remarkable to notice the dominance of framing studies (see Luther and Zhou, 2004; Tian and Stewart, 2005; Beaudoin, 2007) while so far only a small body of research (see Chiang and Duann, 2007) has analyzed SARS by applying discourse 
analysis as this article strives to do so. For this purpose, we will draw upon Chouliaraki's theory on the mediation of suffering.

\section{Regimes of pity and discourses of news: Chouliaraki's model}

Applying discourse analysis (cf. infra), Chouliaraki (2006) drew up a model of analyzing mediated representations of distant suffering by identifying three regimes of pity and three corresponding discourses of news, involving different degrees of moral and emotional involvement by the spectator: adventure news, emergency news and ecstatic news. Chouliaraki (2006: 98) refers to adventure news as "adventuristic reports on irrelevant misfortune". The distant Other is hereby presented as no cause for concern or action, thus blocking any engagement or feelings of compassion. Emergency news is news that produces pity in its representation of suffering as well as the option for action on distant misfortune. The spectator can now identify with the remote sufferer who is still a (cultural) Other. In the case of ecstatic news, we feel for and think of the sufferer as our own, as someone who is like 'us'. There is a relationship of reflexive identification as the spectators share with the sufferers the same humanity and threat. Examples of ecstatic news are 9/11 and the 2004 tsunami.

Chouliaraki has developed this typology of Western news discourse in several publications $(2006,2008)$, based on different cases of suffering. In this article we will apply Chouliaraki's theory to one particular case, SARS, and demonstrate how the three regimes can be part of one news cycle with proximity as a crucial factor for determining the category of pity and news. We will argue that an international event can only shift from adventure news to emergency or ecstatic news when proximity fuels the representations and discursive articulations of compassion. Referring to Hanusch (2007), we believe that distance (be it cultural, geographical or psychological) has indeed the potential to block (emotional and 
practical) engagement, involvement and even attention. It is however important to stress that distance does not always lead to indifference, nor does proximity always lead to identification and pity. The mediation of suffering involves more complicated space-time articulations (Chouliaraki, 2006: 42-3). In this article, we acknowledge the potential of proximity as a news value to act as a facilitating factor in such processes of identification and in raising compassion. This premise draws upon insights from psychological studies (Baumeister et al., 1994) which revealed that people display more compassion when they feel close or related to the 'Other' in need. Again, media are important in this process. We care most about those whom we can identify or feel connected with (Moeller, 1999). If human suffering is thus presented by the media as close, relevant and worthy of our response, we will care for the distant sufferer (Chouliaraki, 2006). In this respect, media representations are "conditions of possibility for public action" (Chouliaraki, 2008: 832), such as donating money or any other helping behavior. A second addition to the model of Chouliaraki consists of taking into account not only what is present in the media, but also what is absent or what is neglected by introducing a potential fourth category of news, that is 'neglected news' (cf. infra).

\section{Methodology}

This article's central research question inquires about discourses of power, hierarchy and compassion in news reporting on an international epidemic. For this purpose, we have adapted Fairclough's (1992) model of CDA for the study of the relations between discourse and social and cultural phenomena. The model consists of three dimensions: text, discursive practice (production, distribution and consumption of texts) and the wider social practice. As outlined above, we further draw upon Chouliaraki's typology of news discourses. Before discussing the results, it is however important to elaborate on the field of discourse analysis, after which we will discuss the selection of cases. 


\section{Analyzing news: Critical Discourse Analysis}

Our understanding of discourse dwells upon Jørgensen and Phillips (2002: 1) who propose the definition of discourse as "a particular way of talking about and understanding the world". In other words, discourse in the sense of language use as a social practice. This article refers to social constructionist ${ }^{2}$ approaches to discourse, in particular Critical Discourse Analysis (Fairclough, 1992, 1995). What these approaches have in common is the premise that language is not neutral. Discourses create representations of the world that reflect as well as actively construct reality by ascribing meanings to our world, identities and social relations. We thus consider language to be both constitutive of the social world as well as constituted by other social practices (Phillips, 2006). This implies that discourse should not be reduced to language alone. Henceforth, social constructionist approaches require that discourse should be empirically analyzed within its social context (Jørgensen and Phillips, 2002); text analysis alone is not sufficient. Text should be understood "as a complex set of discursive strategies that is situated in a special cultural context" (Barthes cited in Fürsich, 2009: 240).

CDA emerged in the late 1980s as an interdisciplinary European school of discourse studies and "[s]ince then, it has become one of the most influential and visible branches of discourse analysis" (Blommaert and Bulcaen, 2000: 447). Power in general and issues of power asymmetries, manipulation and exploitation in particular are the central focus of many investigations within the field. Critical discourse analysts typically stress "patterns of domination whereby one social group is dominated by another" (Phillips, 2006: 288) and reserve the concept of discourse for text, talk and other semiological systems while distinguishing between discursive and other social practices. According to Richardson (2007), CDA is thus mainly used to explore how discourses are realized linguistically in texts to constitute knowledge and social relations, such as a relationship of involvement and 
compassion with a distant 'Other'. Focus is put on the way these power relations are enacted, reproduced and challenged by discourse. Characteristic for CDA is also the stress on intertextuality defined as a blended environment in which different kinds of texts condition each other in order to legitimate certain worldviews (Chouliaraki and Fairclough, 1999).

\section{Selection of cases}

We have selected the SARS epidemic of 2003 because the outbreak caused worldwide anxiety and fear, though it was initially perceived as a local Asian phenomenon. The shift from a local to a global news event co-occurred with the spread of the disease across the globe and was largely fuelled by the high fatality rate $(9.6 \%)$ of the new unknown disease and its proximity to Western audiences. SARS was also the first severe infectious disease that emerged in the $21^{\text {st }}$ century and had an enormous social, economic and political impact (Chiang and Duann, 2007). Consequently, the epidemic received substantial media coverage, which since then has only been matched by the 2009 outbreak of the Mexican swine flu. Figure One shows the news coverage of SARS by Flemish broadcasters VRT and VTM. The peaks in the graph coincide with the key events in the global battle against SARS.

Figure One. SARS's news cycle (total coverage in seconds, VRT and VTM, 2003) 


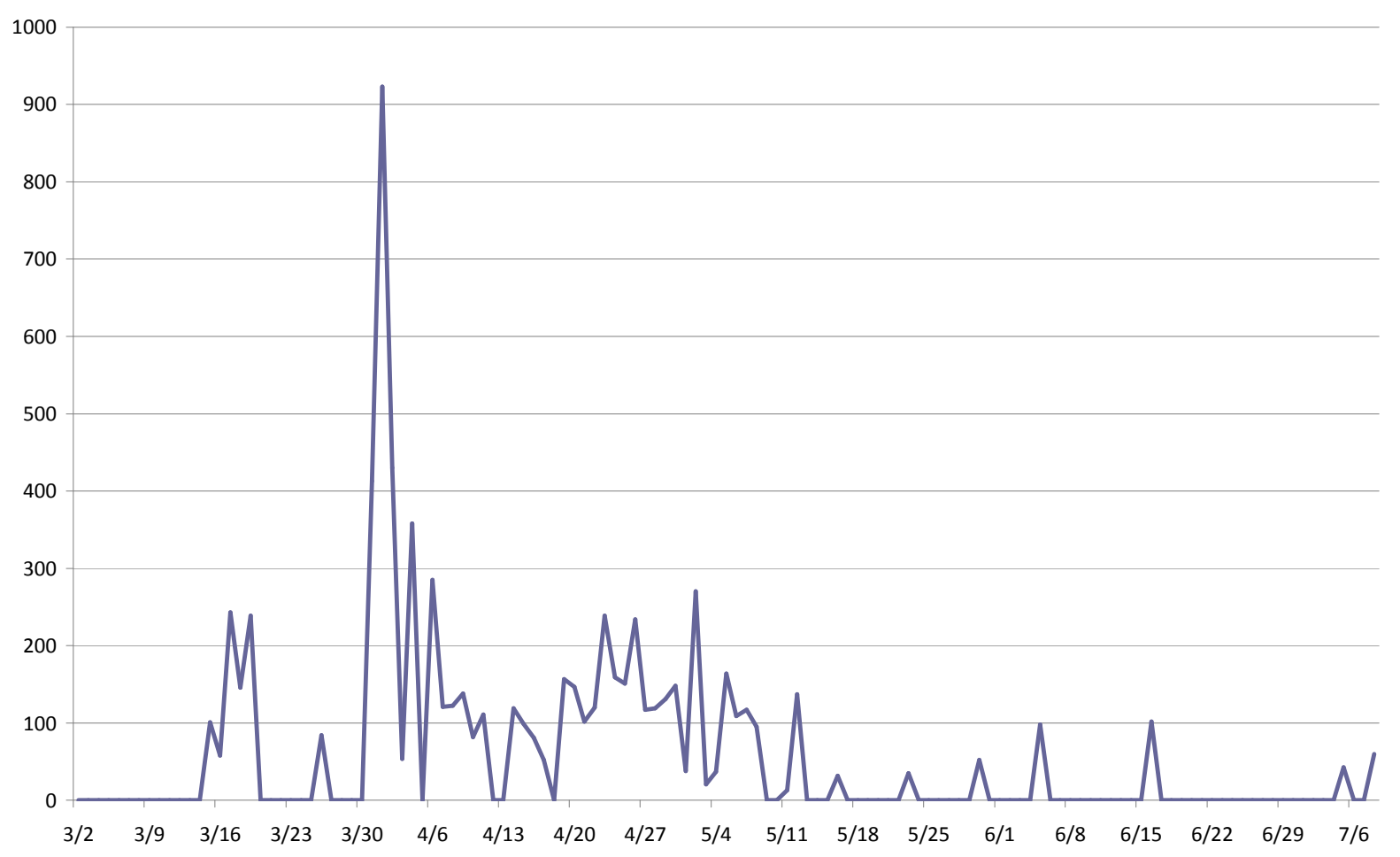

Source: based on data retrieved from the Electronic News Archive (ENA), University of Antwerp (www.nieuwsarchief.be)

A first key event is situated mid-March when following the spread of the disease the WHO issued a global alert including travel advisories. The latter were strengthened by the end of March as the cumulative world total of infections passed the 2,000 mark. Boosting the local news cycle at that moment were reports on the first potential cases of SARS in home country Belgium. This is also the first and only time that SARS succeeded in breaking through the then dominant news story on the Iraq war. After this, the news coverage dropped and the war in Iraq took the headlines again. A next peak in the news timeline was driven by the announcement of 339 previously undisclosed SARS cases in China on April 20. From May onwards, media attention for SARS was relatively scarce and focused exclusively on Asia again and on travel advisories being lifted or extended by the WHO. On July 5, the world's last SARS hotspot, Taiwan, was taken off the WHO list of SARS-affected areas, which spurred some final seconds of coverage for the epidemic. 
For our analysis we have selected four discursive moments, drawing upon the above discussed key events. The first moment is situated in the period that SARS was downplayed by Chinese authorities and did not receive any media attention. The second one deals with SARS's pandemic potential as it develops from a rather local Chinese disease to a global threat that triggered average media attention in Belgium. This second moment was interrupted by three days of SARS-induced panic in Belgium. Several potential cases of SARS were reported and they received substantial media attention. We are now at the top of the news cycle. After these cases appeared to be false alarm, we return to the second discursive moment and an average coverage pattern for the disease. From May onwards, media attention for SARS is slowly fainting away with some minor peaks; this is our fourth moment of analysis. In total 57 news items on SARS were analyzed.

\section{Results and discussion}

As indicated above, Fairclough $(1992,1995)$ identified three dimensions of CDA: text, discursive practices and social practices. In what follows, we will discuss the dimension of text separately for each discursive moment.

\section{Text}

According to Richardson (2007), analyzing a text is analyzing the choices made by the author of that text. For each selected discursive moment, we will discuss the multimodal texts that make use of written language, visual images and sound.

\section{Discursive moment 1: a period of media silence}

Although the first known case of SARS occurred in November 2002, it lasted till midFebruary 2003 before the disease was covered in a newspaper called Guangming Daily and on 
the Chinese state television station $C C T V$. These first reports followed the Chinese Ministry of Health's announcement of the outbreak which at the time had already infected 300 people and led to the death of five other (Beaudoin, 2007: 510-2). As mentioned above, it took another month before the global news media picked up on the epidemic. In Flanders, the first item on SARS was broadcast on March 15.

This period of absence or media silence is very meaningful to critical discourse analysts. Richardson (2007: 93) states that it is important to "recognise that textual or journalistic meaning is communicated as much by absence as by presence; as much by what is 'missing' or excluded as by what is remembered and present." Which subtle underlying meanings can thus be identified from this period of outright silence in international press? First, the lack of coverage on SARS has an important ideological aspect as Western media commonly categorize China as the unknown, communist 'Other' which often results in highly critical reporting and the use of Cold War stereotypes (Leung and Huang, 2007). This negative image and unfavorable reputation of China was further enforced by the cover-up and mismanagement of SARS by the authorities. In other words, the outbreak of the disease fitted into a pre-defined Western news frame on China and henceforth lacked the news value of unexpectedness. Secondly, another critical news value that was missing was proximity, one of the key focuses of our analysis. At this moment in time, SARS represented a purely Chinese medical issue with no relevance towards Belgium or any other Western country, hence the absence of any coverage. This reveals a very euro- and ethnocentric vision of news media in their coverage of global suffering. Thirdly and related to the former, the broader geo-political context is also very crucial during this timeframe as international news was then dominated by the impending war in Iraq where Western (self) interest was clearly very present. Based on the newsworthiness devoted by VRT and VTM to both issues, a Euro-American hierarchy of issues and countries can thus be recognized. 
In conclusion for this first moment, we may add a fourth category of news to Chouliaraki's model, that is a cluster of 'neglected news'. From the perspective of pity, we can refer to it as a subdivision of Chouliaraki's regime of adventure news given the shared status of the distant Other as no cause for concern or action. As news coverage is absent here, involvement of the public is logically non-existing. This newly proposed class of news echoes the power of the media to sway public perception by choosing what to publish and what not (Berry et al., 2007). It also stresses the meaning of absence in news coverage and further confirms that for most people disasters exist only when they are recognized or covered by the media (Benthall, 1993; Franks, 2008; Cottle, 2009). Related to the dimension of social practices (cf. infra) and referring to Hall's (2001) notion of Self and Other construction, we could even argue that the rejecting of others by for instance silencing them is an important element in establishing the identification of us, the Western Self. Previous research on disasters (Joye, 2009) demonstrated that what was 'missing' or excluded in disaster coverage is mainly misfortune affecting the distant Other in developing countries, thus reflecting existing global power relations and hierarchies.

\section{Discursive moment 2: SARS as emergency news}

Moment one indicated that it is important to reflect on what is included and what is excluded, but as Fairclough (1995: 4) pointed out, it is also crucial to analyze what is put on the foreground and what is put on the background in mediated representations. This will become clear when discussing the second discursive moment. This 'moment' actually encompasses the long period from mid-March till the first days of May, minus the couple of days that SARS was falsely reported in Belgium (cf. discursive moment 3).

Overlooking these two and a half months, a significant pattern in the coverage is noticeable. Foreign facts are generally accompanied by one or more items related to Belgium. 
The latter are usually put on the foreground while their objective severity in terms of affected and killed persons was unquestionably lower. In other words, news discourses prefer a potential threat to 'us' above an actual threat to 'them'. This resonates with the rather euroand ethnocentric coverage by both stations and the key issue of proximity that can also be achieved or strengthened through the practice of domestication (cf. infra). Regarding SARS, domestication was achieved by providing among others (telephone) interviews with Belgians in Hong Kong, items on precautions taken by the national airport, interviews with Belgian medical experts who inserted proximity in the texts by resuming and thus domesticating the general WHO's news releases, and more human-interest driven coverage of concrete cases such as a local wedding that was held in open air out of fear for SARS and Belgian expats living in Peking.

Next to an increased sense of proximity, the visual and spoken articulation of SARS is relevant for this discursive moment. First, for television news, viruses and their impact are very difficult to visualize, not in the least due to their microscopic size. News agencies and television stations thus tackled the epidemic by abundantly providing images of hospitals, nurses and doctors, and laboratories where researchers in 'spacesuits' worked hard to analyze the virus. For example, when interviewing a Belgian virologist, the dominant visual frame on both channels was the characteristic interior of a laboratory. Regarding SARS's impact, the element of (global) panic was best illustrated through images of anonymous people wearing surgical masks while its effect on global tourism and economy was mainly visualized by footage of airports and empty restaurants. Interviewing ordinary people and officials was another technique of grasping the panic and fear. These strategies of visualization resulted in a dominance of medical imagery that made the epidemic urgent and relevant to the spectator and his/her health. In contrast, the images of airports could be interpreted as slightly distancing the disease by stressing its association with travelling and its exotic, hence distant 
nature. Secondly and focusing on the verbal voiceover, the use of military vocabulary ("the aggressive lung disease SARS", "beating the extremely contagious disease", “containment", "SARS is quickly conquering the world", "the virus attacks"...) was predominant in the news discourses on SARS. This is consistent with findings from Sontag (1989) who found that news reporting on diseases generally uses such invasion imagery and the metaphor of fighting a war. Thirdly, another element deals with the category of agency in suffering. Verbal and visual strategies articulated a contrast between an active 'us' (the West, Belgium) and a passive 'them' (the affected Asian countries and particularly China) for instance in their dealing with the epidemic. To give just some examples, for three days in a row news reports on SARS in Hong Kong and China kept on showing the same archive footage of sealed buildings and a hospital's jam-packed waiting room as to visually underline that no progress was yet made in China's battle against SARS. In terms of the related verbal text, we can refer to the dominant use of a passive voice by the anchors and in the voiceover (eg "attempts to contain the disease were taken by the Chinese government"). In contrast, Western actors were portrayed to actively and successfully address the threat of a SARS outbreak. Around midMarch, news items already reported extensively on the many precautions and measures taken (cf. infra).

In brief, for Belgian television stations and spectators SARS has acquired emergency status by fulfilling the criterion of relevance to a Western centre (Chouliaraki, 2006: 144). In other words: proximity created newsworthiness. The dramatic visualization further construed the epidemic as worthy of Belgian spectators' attention and involvement.

\section{Discursive moment 3: three days of ecstatic news}

On March 31, SARS entered what had till then been perceived as a zone of safety: Belgium. Proximity was now at its maximum and media attention for the "feared and deadly" disease 
skyrocketed. The mediated representation of SARS during these three days displayed several characteristics or indications of what Chouliaraki describes as ecstatic news.

Regarding identification, sufferers and spectators now coincide as they belong to the same community. The sufferer is one of 'us' and his/her misfortune is presented as very close and relevant of our response and action. For instance, the VTM anchorperson introduced a news item on SARS by stressing "how very close by" the disease now is. On March 31 an item by VRT was announced with the headline: "now also present among us?", hence expressing a community feeling as illustrated by the use of the all-inclusive "us". The anchors and journalists furthermore emphasized such discourses of national unity and proximity by consistently referring to "our country" and "our fellow countrymen" in their voice-overs and testimonies. The relevance and urgency of the local suffering was also visualized by a shot of a fast-driving ambulance with lights flashing and siren blaring. This articulated sense of urgency and proximity is further enforced by the live footage and testimonies from journalists present at the scene. This direct link commands an urgent rapport between the sufferer and the spectator, who is positioned as a witness by the televisual mediation. We also obtain access to the scene of suffering via several interviews with government officials, emergency helpers and neighbors of the allegedly infected persons.

In addition to this articulated sense of what Chouliaraki (2004: 191) refers to as "instantaneous proximity", VTM and VRT abundantly stressed the swift measures taken by the Belgian government and the effectiveness of a well-prepared health system. For example, spectators were informed on travel advisories and the installation of a national crisis centre. Footage of the crisis centre revealed a well-equipped and hardworking staff, seemingly in control of the situation. Further comments by an expert in the television studio underwrote this dominant discourse of control, resulting in feelings of safety. Such immediate and public denouncing of panic is understandable, despite its discursive side-effect. Referring to the 
element of intertextuality, this particular focus of the news texts further cultivated the sharp contrast between 'us' and 'them' as the Chinese government was at the time portrayed as downplaying and mismanaging the crisis (cf. discursive moment two and social practices).

In retrospective, this particular phase in the news cycle is the best illustration of the impact of proximity on news discourses. Two potential cases of SARS in Belgium ('us') receive disproportionally more coverage than all other infected people (distant 'Others'), including the many lethal victims of the epidemic. Furthermore, these news items logically expressed the most intense feelings of compassion and pity. Although the particular event itself may not be so extraordinary that it "cannot be contained in an ordinary news broadcast" or that it should be constituted as a global historical rupture (cf. Chouliaraki's definition of ecstatic news, 2006: 157-8), we argue that it is precisely the proximity of the events that enacted a nearly ecstatic mode of representation, albeit this mode was limited in space (Belgium) and time (three days). Once the cases proved to be false, the element of proximity loses substantially in impact and the news coverage returns to a mode of emergency news. As in the subsequent weeks the threat and relevance of SARS to Belgium and the West steadily diminishes, we encounter a last phase in the coverage that can be labeled as 'adventure' news.

\section{Discursive moment 4: SARS as 'adventure' news}

We put 'adventure' between inverted commas as we are now in the aftermath of the epidemic. Involvement or proximity is no longer explicitly present in the coverage but given the concept of intertextuality, these short reports cannot be seen separate from the substantial media attention that SARS received in March and April. As argues van Dijk (2009: 192), each unit of discourse is produced as being conditioned by previous units and should thus be interpreted and analyzed as such. 
Nonetheless, we found several indications of what Chouliaraki defines as adventure news. This category of news consists of only short reports, singular space-times and simple multimodality (Chouliaraki, 2006: 10). The reports on the last days of SARS do not make a very media-friendly and sensational story. The primarily descriptive news texts focus on the situation in Asia and mainly deal with impartial updates on travel advisories and the total number of affected and killed persons. Proximity is replaced by a maximized emotional distance between the spectator and the sufferer. The spectator is no longer motivated to care for or display much empathy with the distant 'Others'. In these last weeks of coverage, SARS failed to fulfill the criteria of relevance or closeness to Belgium or the West and subsequently dropped in newsworthiness.

\section{Discursive practices}

Representations of reality, which news items actually are, are always social constructs. In addition to and in order to surpass the level of mere textual analysis, we need to refer to discursive practices in the sense of structural and functional properties of the news gathering, dissemination and reporting process that limit the choice of journalists. ${ }^{3}$ Discourse is after all context-dependent (Phillips, 2006) and news is the outcome of a range of specific professional and institutional practices (Fairclough, 1995).

A first relevant contextual dimension concerns the economy of news production and access to information and footage. Due to high production costs, most media depend on agency materials for visual coverage of foreign events. Related to the foreign cases of SARS, Flemish journalists were not covering the events themselves. Henceforth, VRT and VTM needed to rely on footage provided by the two major players APTN (USA) and ReutersTV (UK), who dominate the global news market. These two news providers not only decide which news items get distributed but they also set the standard of content and form of news. 
Such access to and control over international news is believed to be an important symbolic resource of power (van Dijk, 2001). During the second discursive moment and especially in the third, VRT and VTM did however broadcast own footage. The footage mainly consisted of interviews with a local expert on viruses, with officials of the national airport or with spokesmen of the hospitals where potential Belgian victims of SARS were held in quarantine. During the third moment of ecstatic news, the news broadcasts included live footage as well.

Secondly, SARS was mainly a foreign news event and all television stations hold on to a particular editorial policy regarding for example the balance between domestic and foreign news. Public service channel VRT and commercial channel VTM both maintain a good reputation regarding the quality and amount of their foreign news coverage. Previous research by Joye and Biltereyst (2007) has indicated an average percentage of $47.8 \%$ international news for VRT and $42.1 \%$ for VTM. However, included in these percentages were also socalled domesticated items in which journalists frame a foreign event within the national context of their public, for example by focusing on Belgian tourists in the affected region or by interviewing local experts. According to Manning (2001: 62), too much domestication can produce "a rather Eurocentric if not ethnocentric picture of global affairs." Events happening in neighboring countries, Western-Europe or the USA, and news events with the occurrence of Western victims appear to have a substantially greater chance to be selected and covered in greater detail than others (Joye and Biltereyst, 2007). The cited study pointed out that Belgian television news adheres to such a Western vision of the world in its selection and coverage of events, as was also the case with the SARS outbreak.

A third contextual level is an institutional one. The corporate policy and mission of a television network can be a significant element of editorial context, for example in determining the newsworthiness of events and even how they will be covered. Despite a very high level of similarity in the events selected and the footage shown, a subtle difference in 
news reporting between VRT and VTM is noticeable. For instance, commercial channel VTM tends to round-up the figures in their reports on the number of affected persons. Other subtle differences between the two stations deal with the use of sensational adjectives and soundbites ("extremely contagious", "fear psychosis", "very deadly" ...) as well as with the domestication of the events. Public broadcaster VRT made less use of both.

\section{Social practices}

News discourse is also permeated by structures, institutions and values from outside the newsroom such as economy, politics and ideology (Richardson, 2007). Neither journalists nor news organizations can escape the fact that they are tied to a broader social system (Shoemaker, 1991). Referring to these wider social practices, we need to ask whether the news texts will help to continue or reproduce inequalities and other undesirable social practices. This dimension of Fairclough's model essentially refers to ideological effects and hegemonic processes (Blommaert and Bulcaen, 2000). Although van Dijk (2009: 199) admits that it is theoretically and empirically impossible to provide a complete and detailed "account of the ideologies involved and the structures of news that are controlled by them", he states that a polarization between the ingroup ('us', a positive self-image of a social group) and the outgroup ('them', assessed and represented in a negative way) is characteristic of many such ideological structures. In terms of the presented research, we have found several indications of such socio-cultural polarization in the mediation of the SARS outbreak (cf. the textual analysis).

Although SARS was very negative by nature, a positive representation of the West ('people like us') was achieved in emphasizing agency, apparent control over the situation and effective crisis management skills. This was for instance illustrated by several interviews with Belgian experts, spokesmen of the national airport and (Western) officials of the WHO. 
In their reports, VRT and VTM continuously stressed the safety measures taken by the Belgian government and the high effectiveness of medical support in Belgium as well as in the surrounding countries. Chinese people ('ethnic Others') were by contrast negatively depicted as passively undergoing the misfortune and overpowered by a new unknown force of nature. The consistent voiceover references to the Chinese government's cover-up as well as to the subsequent inability of taking control over the epidemic further underlined this rather negative representation of the Other. Especially during the first news reports, helplessness and chaos appeared to dominate its representation. The use of such pre-established images and stereotypes resonates with the Orientalist (cf. Saïd, 1987) discourse of civilized 'West' (the ingroup, identified as superior) versus barbarian 'Other' (the non-Western outgroup, categorized as inferior). This socio-cultural polarization was best visualized on April 3 when Western experts from the WHO were flown in to inspect the Guangdong region where the disease originated and were welcomed by locals as 'saviors' who would finally take care of the problem that their own government had ignored for such a long time. It is also important to recognize that these bipolar oppositions "are not defined equally but hierarchically i.e. the second term is usually seen as a corruption of the first" (Creeber, 2006: 46, original italics; see also Hall, 2001). This by mediation constituted hierarchy is moreover a reflection of the well-known hierarchies of capitalism in which the rich are valued more than the poor. International news coverage is permeated by such power relations of inequality.

\section{Conclusion}

News carries a unique signifying power, a power to represent events in particular ways (Fairclough, 1995). This article investigated the representation of SARS by Flemish television stations and drew upon Chouliaraki's typology of pity and news discourse. Based on the SARS case, we are able to make suggestions to elaborate this model on three levels. First, we 
attempted to illustrate that Chouliaraki's model is a very useful and relevant model to analyze international news coverage of one particular case and to identify the different phases of such a news cycle. Secondly and acknowledging the importance of 'absence' in news coverage, we proposed a fourth category of news discourse that focuses on the practice of excluding events by news media. Following Richardson (2007), we believe that journalistic meaning is expressed as much by absence as by presence. Thirdly, our analysis demonstrated that proximity is a key factor in determining the category of news discourse and hence, the mediated regime of pity and compassion. A high degree of proximity induces identification, feelings of compassion and of course substantial media attention. The latter was best illustrated when potential SARS cases were reported in Belgium. During these three days of ecstatic news, the dominant hierarchy of the 'safe' centre and the 'dangerous' periphery was reversed. For a brief moment in time and space, the spectator and the sufferer coincided. During the other, less mediatized, phases of the news cycle, VRT and VTM have continued to cover SARS from a principal euro- and ethnocentric perspective. Henceforth, our interpretation further supports the claim that Western news media discursively reproduce a certain kind of world order, mainly a Euro-American centered one.

In conclusion, we argue that the news coverage of international crises such as SARS constructs and maintains the socio-cultural difference between 'us' and 'them' as well as articulating discourses of global power structures and a division of the world in zones of poverty and prosperity, danger and safety. Cause and logical consequence of this is the key role of proximity in news discourses on distant events.

\section{Notes}


1. Flanders is the Northern Dutch-speaking region of Belgium. Together with the Frenchspeaking Wallonia, bilingual Brussels and the German-speaking region it constitutes the federal state of Belgium.

2. Social constructivist approaches assume that reality is socially constructed and thus reject positivism's demarcation between the objective observer and reality waiting to be observed (Burr, 1995).

3. Recently, scholars such as Philo (2007), Carvalho (2008) and Fürsich (2009) have engaged in a methodological debate on the appropriateness of CDA to analyze the context of production, the impact of external factors and the audience's reactions.

\section{References}

Adams, W. C. (1986) 'Whose lives count? TV coverage of natural disasters', Journal of Communication 36(2): 113-122.

Associated Press (2003) Key events in the global battle against SARS. July 5, 2003.

Baumeister, R. F., Stillwell, A. M. and Heatherton, T. F. (1994) 'Guilt: an interpersonal approach', Psychological Bulletin 115(2): 243-267.

Beaudoin, C. E. (2007) 'SARS news coverage and its determinants in China and the US', International Communication Gazette 69(6): 509-524.

Belloni, H., Douma, N., Hilhorst, T., Holla, J. and Kuiper, G. (2000) Weergave van 'natuurrampen' in Nederlandse dagbladen. (Representation of 'natural disasters' in Dutch newspapers), www.disasterstudies.wur.nl

Benthall, J. (1993) Disasters. Relief and the media. London: Tauris.

Berry, T. R, Wharf-Higgins, J. and Naylor, P. J. (2007) 'SARS Wars: an examination of the quantity and construction of health information in the news media', Health Communication 21(1): 35-44. 
Blommaert, J. and Bulcaen, C. (2000) 'Critical Discourse Analysis', Annual Review of Anthropology 29: 447-466.

Boltanski, L. (1999) Distant suffering. Morality, media and politics. Cambridge: Cambridge University Press.

Burr, V. (1995) An introduction to social constructionism. London: Routledge.

CARMA International (2006) The CARMA report on Western media coverage of humanitarian disasters, http://www.carma.com/research/

Carvalho, A. (2008) 'Media(ted) discourse and society: rethinking the framework of Critical Discourse Analysis', Journalism Studies 9(2): 161-177.

Chiang, W. and Duann, R. (2007) 'Conceptual metaphors for SARS: 'war' between whom?', Discourse \& Society 18(5): 579-602.

Chouliaraki, L. and Fairclough, N. (1999) Discourse in late modernity. Edinburgh: Edinburgh University Press.

Chouliaraki, L. (2004) 'Watching 11 September: the politics of pity', Discourse \& Society 15(2-3): 185-198.

Chouliaraki, L. (2006) The spectatorship of suffering. London: Sage.

Chouliaraki, L. (2008) 'The media as moral education: mediation and action', Media, Culture \& Society 30(6): 831-852.

Cottle, S. (2009) Global crisis reporting. Journalism in the global age. Berkshire: Open University Press.

Creeber, G. (2006) 'Decoding television. Issues of ideology and discourse', in G. Creeber (Ed) Tele-Visions. An introduction to studying TV: 44-59. London: BFI.

Fairclough, N. (1992) Discourse and social change. Cambridge: Polity press.

Fairclough, N. (1995) Media discourse. London: Edward Arnold.

Franks, S. (2008) 'Getting into bed with charity’, British Journalism Review 19(3): 27-32. 
Fürsich, E. (2009) 'In defense of textual analysis. Restoring a challenged method for journalism and media studies', Journalism Studies 10(2): 238-252.

Gaddy, G. D. and Tanjong, E. (1986) 'Earthquake coverage by the Western press', Journal of Communication 36(2): 105-112.

Gans, H. (1979) Deciding what's news. New York: Pantheon books.

Gaunt, P. (1990) Choosing the news. New York: Greenwood Press.

Hall, S. (2001) 'The spectacle of the Other', in M. Wetherell, S. Taylor and S. J. Yates (eds) Discourse theory and practice: $324-344$. London: Sage.

Hanusch, F. (2007) 'Publishing the perished: the visibility of foreign death in Australian quality newspapers', Media International Australia, 125:.29-40.

Jørgensen, M. and Phillips, L. (2002) Discourse analysis as theory and method. London: Sage. Joye, S. and Biltereyst, D. (2007) 'All quiet on the...? Een analyse van het buitenlandaanbod van VRT en VTM' (An analysis of foreign news on VRT and VTM), in M. Hooghe, K. De Swert and S. Walgrave (eds) De kwaliteit van het nieuws (The quality of news): 71-84. Leuven: Acco.

Joye, S. (2009) 'The hierarchy of global suffering: a critical discourse analysis of television news reporting on foreign natural disasters', The Journal of International Communication 15(2): 45-61.

Kamalipour, Y.R. (Ed) (2002) Global communication. Belmont: Wadsworth.

Kim, H. S. and Lee, S. T. (2008) 'National interest, selective sourcing and attribution in air disaster reporting', The Journal of International Communication 14(1): 85-103.

Lee, C. C., Chan, J. M., Pan, Z. D. and So C. Y. K. (2002) Global media spectacle. New York: State University of New York Press.

Leung, C. C. M. and Huang, Y. (2007) 'The paradox of journalistic representation of the Other', Journalism 8(6): 675-697. 
Luther, C. A. and Zhou, X. (2004) 'Within the boundaries of politics: news framing of SARS in China and the United States', Journalism and Mass Communication Quarterly 82(4): 857872.

Manning, P. (2001) News and news sources. A critical introduction. London: Sage.

Moeller, S. D. (1999) Compassion fatigue. How the media sell disease, famine, war and death. London: Routledge.

Nederveen Pieterse, J. (1990) Wit over zwart. Beelden van Afrika en zwarten in de Westerse populaire cultuur (White over black. Images of Africa and blacks in Western popular culture). Amsterdam: Koninklijk Instituut voor de Tropen.

Phillips, L. (2006) 'Doing Discourse Analysis. A brief introduction to the field', in N. Carpentier et al. (eds.) Media technologies and democracy in an enlarged Europe: 285-294. Tartu: Tartu University Press.

Philo, G. (2007) 'Can Discourse Analysis successfully explain the content of media and journalistic practice?', Journalism Studies 8(2): 175-196.

Richardson, J. E. (2007) Analysing newspapers: an approach from Critical Discourse Analysis. New York: Palgrave Macmillan.

Saïd, E. (1987) Orientalism. New York: Penguin.

Shoemaker, P. (1991) Gatekeeping. London: Sage.

Simon, A. F. (1997) 'Television news and international earthquake relief', Journal of Communication 47(3): 82-93.

Singer, E. and Endreny, P. (1993) Reporting on risk. New York: Russell Sage Foundation. Sontag, S. (1989) Illness as metaphor. New York: Picador/Farrar, Straus and Giroux.

Tian, Y. and Stewart, C. M. (2005) 'Framing the SARS Crisis: a computer-assisted text analysis of CNN and BBC online news reports of SARS', Asian Journal of Communication 15(3): 289-301. 
University of Antwerp, Electronic News Archive (ENA), http://www.nieuwsarchief.be.

Van Belle, D. A. (2000) 'New York Times and network TV news coverage of foreign disasters', Journalism and Mass Communication Quarterly 77(1): 50-70.

van Dijk, T. A. (2001) 'Critical Discourse Analysis', in D. Schiffrin, D., Tannen and H. E. Hamilton (eds) The handbook of Discourse Analysis: 352-371. Malden: Blackwell.

van Dijk, T. A. (2009) 'News, discourse, and ideology', in K. Wahl-Jorgensen and T. Hanitzsch (eds) The handbook of journalism studies: 191-204. New York: Routledge.

WHO (2003) Summary of probable SARS cases with onset of illness from 1 November 2002 to 31 July 2003, http://www.who.int/csr/sars/country/table2004_04_21/en/index.html

Zhang, E. and Fleming, K. (2005) 'Examination of characteristics of news media under censorship', Asian Journal of Communication 15(3): 319-339.

Zhang, X. (2006) 'Reading between the headlines: SARS, Focus and TV current affairs programmes in China', Media, Culture \& Society 28(5): 715-737. 